\title{
Environmental Justice and Green Infrastructure in the Ruhr. From Distributive to Institutional Conceptions of Justice
}

\author{
Karsten Zimmermann ${ }^{\star \dagger}$ and Dahae Lee ${ }^{\dagger}$ \\ Faculty of Spatial Planning, Technical University of Dortmund, Dortmund, Germany
}

\section{OPEN ACCESS}

Edited by:

Pedro Roberto Jacobi,

University of São Paulo, Brazil

Reviewed by:

Klemens Laschefski,

Federal University of Minas

Gerais, Brazil

Luciana Travassos,

Federal University of ABC, Brazil

${ }^{*}$ Correspondence:

Karsten Zimmermann

karsten.zimmermann@tu-dortmund.de

tThese authors have contributed equally to this work and share first authorship

Specialty section:

This article was submitted to Urban Greening,

a section of the journal

Frontiers in Sustainable Cities

Received: 20 February 2021 Accepted: 04 May 2021

Published: 07 June 2021

Citation:

Zimmermann K and Lee D (2021)

Environmental Justice and Green Infrastructure in the Ruhr. From

Distributive to Institutional

Conceptions of Justice.

Front. Sustain. Cities 3:670190.

doi: 10.3389/frsc.2021.670190
Over the last 50 years, the Ruhr region experienced a remarkable transformation from an industrial to a post-industrial region. With regard to the rehabilitation of the environmental damages of more than 100 years of coal mining and steel production, investment in green infrastructure, and the creation of regional landscape parks constituted one of the main pillars of the economic and physical transformation of the region. However, little is known about the social effects of this green transformation. Many observers state that the Ruhr area is sharply divided by an east-west line (the A40 Highway) and in fact the Emscher zone was hit most by environmental degradation. We argue that environmental justice is a question of scale. While on the regional scale, the investments made in the Emscher zone can be seen as a trial to balance and repair a long-standing unequal provision with environmental qualities (not least parks), on a smaller scale (i.e., cities and neighbourhoods) we can demonstrate that in the cities of the Emscher zone environmental inequality is still observable. Some neighbourhoods benefit stronger from investment in regional parks and green infrastructure than others. The paper will describe the Emscher green regeneration programme and will give detailed insights into two cities of the Ruhr (including maps and data analysis).

Keywords: green infrastructure, post-industrial region, Ruhr region, governance, environmental justice

\section{INTRODUCTION}

The health and well-being of citizens is largely influenced by the environment they live in. The impact of urban environment on humans has been widely studied, but it was only recently that the racial and socio-economic dimension is included. Starting as a social movement in the 1980s in the US, environmental justice has become a global movement and a concern in many cities (Stephens, 2007). Environmental justice in the procedural sense refers to "the fair treatment and meaningful involvement of all people regardless of race, colour, national origin, or income with respect to the development, implementation, and enforcement of environmental laws, regulations, and policies" (EPA, 2021). Inequality in the access to environmental benefits as well as the exposure to air pollution, noise or contaminated soil and water are the main environmental justice concerns (Stewart et al., 2014). In addition, climate change has become central to the environmental justice discourse as "it has been shown to create unequal impacts on communities of colour, indigenous people, the poor, and on developing countries" (Mohai et al., 2009, p. 425). Against the background of this special issue, we discuss environmental justice with reference to the balanced distribution of and access to green infrastructure. Equitable access to green infrastructure not only provides economic, social and health benefits but it also addresses the impact of climate change for the residential population. 
The empirical case that we are presenting in this contribution is the Ruhr region in western Germany. This region, once the biggest polycentric industrial urban agglomeration in Europe, experienced a remarkable change, in particular with regard to the environmental conditions. The revitalisation of a deteriorated landscape has been an essential element of the economic and physical transformation of this area. Urban green spaces, green corridors, or to use more recent notions such as green infrastructure or eco system services are seen today as a major asset of this post-industrial region (Reimer and Rusche, 2019). The evaluation of the past and present regional planning strategies is mostly positive as the overall environmental quality is much better than it used to be. The Emscher Landscape park, a large system of green spaces and corridors in the north of the Ruhr region, stands out in this regard. However, a closer look and evaluation from the perspective of environmental justice reveals unbalanced access options to green spaces in some cities (Zepp, 2018). Some of the green corridors also shrunk over the last decades. Furthermore, our quantitative research on city level revealed that the supply of green spaces varies considerably across the cities in the Ruhr region. In order to bridge this gap between the perception of a green region on the one side and the limited access to green infrastructure on a smaller scale, we argue that a re-scaled approach is needed when discussing environmental justice in city-regions. This perspective of scaling of environmental policies and discourse has been introduced by Keil and Debbané (2005). Outcomes of environmental policies differ depending on the geographical and institutional scale of implementation.

While on a city-regional scale there is a much higher visibility and provision of green spaces, in particular in an area called Emscher Landscape Park, accessibility to green spaces is more difficult in some neighbourhoods of the Ruhr cities. The Emscher revitalisation programme had beneficial effects for some municipalities but by far not for all. What seems to be a green region shows a high variation of environmental qualities on the level of cities and neighbourhoods. In Bottrop, for instance, the southern parts of the city (Wellheimer Mark) are still waiting for improvements (as envisioned in the Masterplan Emscher Park and the Masterplan Future Emscher: Projekt Ruhr $\mathrm{GmbH}, 2005$; Emschergenossenschaft, 2006). In the south of Dortmund, the Lake Phoenix regeneration project demonstrates a significant increase of blue and green infrastructure. At the same time, this intervention reproduced the north-south divide that characterises the city and raised serious concerns because of an eventual gentrification (Frank, 2021). This raises the normative question of evaluating environmental justice (beyond the questions of methodological measurement). As a result of our study, we argue that the discourse on environmental justice will benefit from a stronger acknowledgement of the theoretical debate on spatial justice (Moroni, 2020).

This paper is written based on the results of a research project called "Future of the City-Region Ruhr" (Zukunft-Stadt-RegionRuhr, ZUKUR $)^{1}$, whose overarching goal was to increase climate

${ }^{1}$ Financed by German Federal Ministry of Education and Research/BMBF, grant number 01LR1721A. resilience and reduce socio-ecological inequality in the cityregion $^{2}$. The paper is structured as follows: it first describes the rise of environmental justice as a social movement and a topic in the academic literature. We review a number of key studies that discuss various aspects of environmental justice to create an analytical framework. The green transition in the Ruhr area and some of the issues regarding environmental justice within the area are introduced. The findings of a quantitative environmental justice analysis of two cities in the Ruhr region are presented, followed by a discussion and conclusion.

\section{THE NOTION OF ENVIRONMENTAL JUSTICE}

The notion of environmental justice first emerged as a social movement in the 1980s in the US when civil rights activists organised to stop the state of North Carolina from dumping 120 million pounds of soil contaminated with PCB in Warren County, which has the highest proportion of African Americans (Mohai et al., 2009). The protests in the county soon received national attention and raised public awareness about the environmental concerns of African Americans and other people of colour (Bullard, 2000; Roberts and Toffolon-Weiss, 2001; Pellow and Brulle, 2005). The term environmental racism was first coined in 1982 by Benjamin Chavis to refer to "any policy, practice, or directive that differentially affects or disadvantageswhether intended or unintended-individuals, groups, or communities based on race or colour" (Bullard, 1996, p. 451). In this tense atmosphere, subsequent events were followed which increased the visibility and momentum of the environmental justice movement (Mohai et al., 2009). The movement was an attempt to respond to environmental inequalities, threats to public health, unequal protection, differential enforcement of environmental regulations, and disparate treatment received by the poor and people of colour (Bullard and Johnson, 2000).

In close relationship with this social movement, environmental justice arose as a topic in the academic literature and found increasing attention in the global south in recent years (Agyeman and Evans, 2004; Travassos et al., 2021; Irazábal, 2021). Starting with a study conducted by the U.S. General Accounting Office in 1983, a series of studies was released that investigated the racial and socioeconomic composition of the communities near hazardous waste sites in the US. Among others, a study by United Church of Christ Commission for Racial Justice (Chavis and Lee, 1987) documented the unequal and discriminatory siting of waste facilities across the US. This study also found out that the percentage of people of colour was the best predictor of where waste sites would be located. In 1990, sociologist Bullard published his now classic book, Dumping in Dixie, which chronicled the convergence of social justice and environmental movements into an environmental justice movement. Since the 1990s, an extensive amount of literature on this topic has been produced by scholars worldwide.

\footnotetext{
${ }^{2}$ We thank all the colleagues involved, in particular Kristina Ohlemeyer and Mathias Schaefer for the graphics in section Methodology. We also thank Prof. Harald Zepp for allowing us to use Figure 2.
} 
Today, hundreds of studies conclude that, in general, there is a significant relationship between the racial and socioeconomic characteristics of a community and levels of exposure to environmental risk (Mohai et al., 2009).

While, traditionally, the environmental justice movement focused on pollution issues affecting the health of population living near toxic sites or infrastructures, more recently, it focuses also on the distribution of environmental amenities (De Sousa Silva et al., 2018). So, for instance, Gould and Lewis (2017) emphasised the importance of analysing the full spectrum of distribution from environmental burdens to environmental benefits such as green infrastructure. Green infrastructure is defined as "an interconnected network of green space that conserves natural ecosystem values and functions and provides associated benefits to human populations" (Benedict and McMahon, 2002, p. 12). The European Commission provides a long list of benefits of green infrastructure in its report Building a green infrastructure for Europe (European Commission, 2013). According to this report, which was an essential back-up for EU funding programmes (i.e., the Green Deal), green infrastructure and nature-based solutions contribute positively to the environment, for instance, by removing pollutants from air and water, protecting against soil erosion, and retaining rainwater. It also has various positive effects on social aspects that range from promoting human wellbeing and health to enhancing tourism and the local economy. Green infrastructure is considered as an effective tool for climate change adaptation and mitigation as well. Lastly, it contributes to biodiversity as it, for example, provides improved habitats for wildlife and ecological corridors.

Green infrastructure is essential to improve the population's wellbeing. Yet, it has been documented that its distribution is uneven across a city or city-region and that some demographic groups have less access to it (De Sousa Silva et al., 2018). It is an environmental justice issue as socio-economically disadvantaged communities are most affected (Byrne et al., 2009; Curran and Hamilton, 2012). A definition of environmental justice includes the right of the entire population to live in a clean and healthy environment (Gould and Lewis, 2017). Hence, priority should be given to areas with highest proportion of vulnerable groups (Gill et al., 2007). Interestingly though, the implementation of green infrastructure to rehabilitate degraded neighbourhoods and, thus, improve wellbeing and environmental justice can have the opposite result, i.e., the increase of the value of land, increase in cost of living and, as an eventual result, displacement of the existing community (Curran and Hamilton, 2012; Pearsall and Anguelovski, 2016; De Sousa Silva et al., 2018). Hence, the concept of "just green enough" emerged; the idea is that neighbourhoods of low environmental quality are improved, but not to the point where gentrification takes place (Curran and Hamilton, 2012).

The concept of environmental justice has been expanding and it is applied to several different topics, from transportation to disaster management (Schlosberg and Collins, 2014). Climate change is not an exception. Climate change is a threat to physical and mental health, and vulnerable communities often face the greatest risks as they live in flood zones or areas exposed to heat
(Travassos et al., 2021). According to a report released by Black Congressional Caucus (2004), although African Americans are less responsible for climate change than other Americans, they are disproportionately burdened by the adverse health effects of climate change as evidenced by, for instance, the number of deaths during heat waves. Indeed, climate change reflects social inequality in several ways, including who causes the problem, who suffers most, who is expected to act, and who has the resources to do so (Mohai et al., 2009). The Hurricane Katrina in 2005 helped to expand the consideration of climate-changing environment in the environmental justice movement (Schlosberg and Collins, 2014). Today, climate change is central to the environmental justice discourse (Travassos et al., 2021).

All in all, the discussion of environmental justice focuses on maldistribution of environmental resources, i.e., marginalised communities experience fewer environmental benefits, more environmental burdens, and less climate change related protection (Schlosberg, 2007). A question now arises as to how environmental injustice can quantitatively be measured, monitored, and evaluated. The City of Berlin was one of the first local governments to develop an environmental justice concept (Köckler, 2017), thereby providing for a detailed description of the environmental quality in each of the city's 447 planning areas (SenSW, 2015). The city used a two-stage process to examine environmental justice, including five core and a number of complementary indicators. Noise exposure, air pollutants, bioclimatic burden, access to green and open spaces, and social hardship belong to the core indicators. Complementary indicators provide for a more in-depth understanding of the situation in various neighbourhoods throughout the city. The available data were aggregated and multiple-load maps created. Berlin's approach served as a model for the environmental justice analysis carried out within the research (Bakunowitsch et al., 2019).

\section{GREEN INFRASTRUCTURE AND ENVIRONMENTAL JUSTICE IN THE RUHR REGION}

From the perspective of environmental justice, the Ruhr area is an interesting object of study Figure 1. The period of rapid industrialisation and urban growth (1870-1970) had a range of adverse effects for the residential population. Air pollution, loss of green spaces, contaminated soil, a degraded river system, and a scattered settlement structure were the main impacts. Environmental damages were, however, not spread evenly all over the region. Due to improvements in mining technology and geological conditions, mining and steel production activities went northwards over a period of 50-60 years. As a result, at the end of the age of mining, the northern parts of the Ruhr region display the highest density of industrial land use and transport infrastructure (Zepp, 2018). The southern parts of the Ruhr area, in contrast, were less affected by environmental damages than the northern parts. This north-south divide is mirrored also in social hardship indicators as well-of communities usually live in the southern parts of the region while disadvantaged 


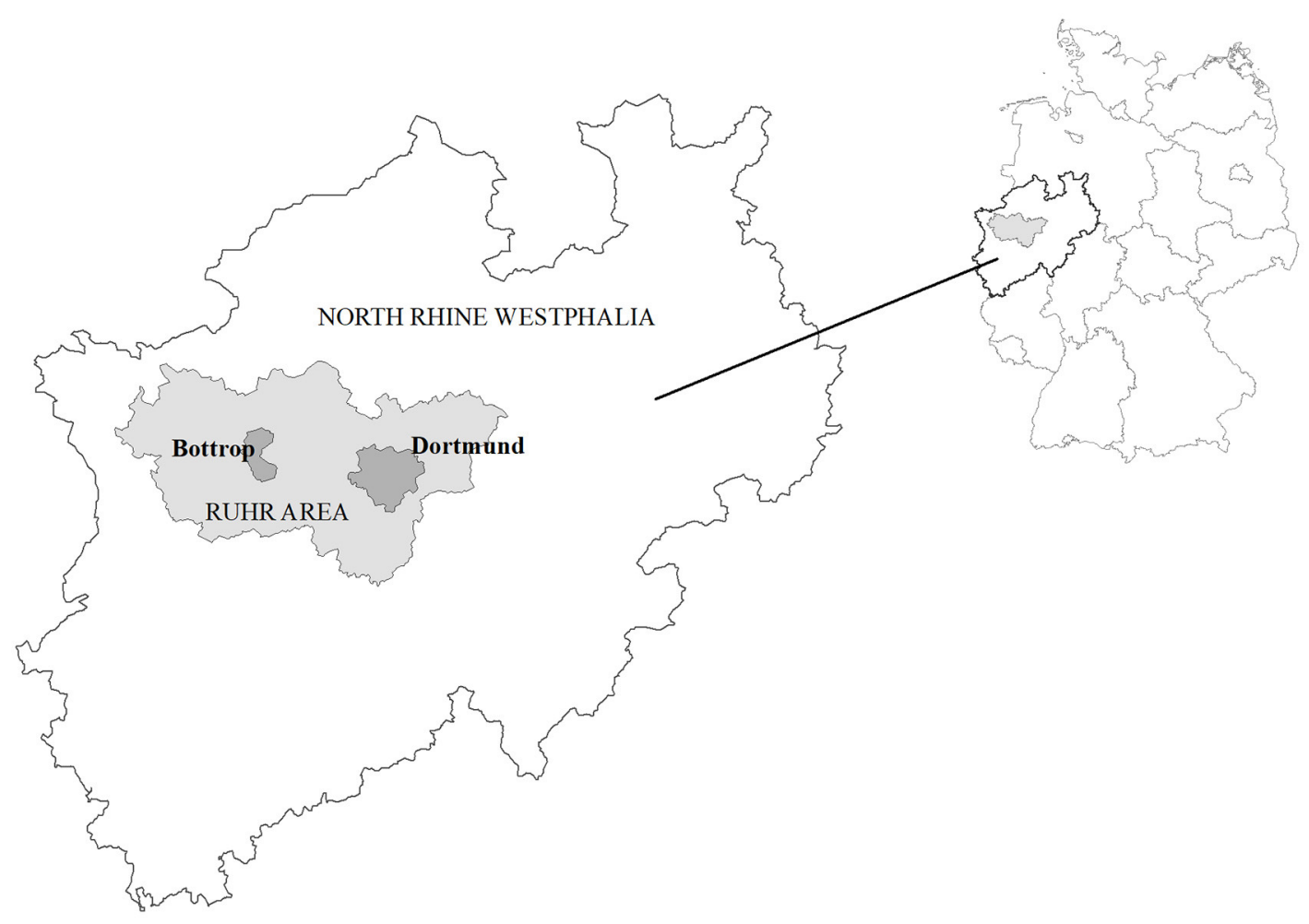

Legend
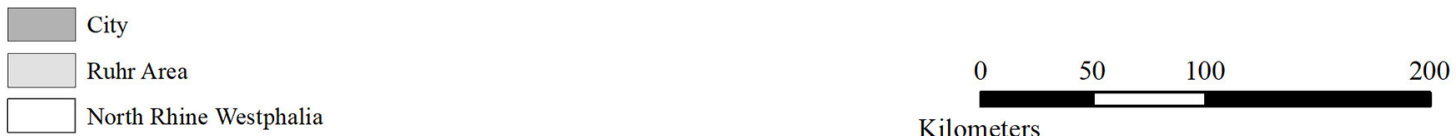

Kilometers

FIGURE 1 | Ruhr area in Germany.

neighbourhoods are more likely to be found in the northern parts (see analysis in section Findings).

The area that was affected most was certainly the Emscher zone in the northwest of the Ruhr area. The Emscher river and its many tributaries were used as an open sewer for industrial and household waste water for a period of more than 100 years. In fact, it is not totally misleading to call this area the dump site of the region, with a highly contaminated river and a degraded landscape being the main result. At the same time the area was densely populated, with many workers and their families living in so called industrial villages (i.e., dense working-class settlements next to the mines and steel works but out of the major cities). Measures to prevent the worst to happen were taken in the first decades of the 20th century. Suggestions to create a system of green corridors were made in 1912. In 1920, a regional planning association was founded and one of its main functions was the separation of settlements through green corridors and the maintenance of green spaces and agricultural land (Regionalverband Ruhr/RVR, 2015). Already before, in 1899, the Prussian government established the Emscher Association, a special purpose body that took care of flood prevention and sanitation. Obligatory members of this association were cities and the large waste water producing firms (mining companies, steel factories). It's important to note that both associations were cross-municipal initiatives.

In the following decades, the idea of green corridors turned out to have a perseverance in city-regional politics. In particular in the 1960s, when the above-mentioned regional planning authority was granted the role of statutory regional planning, the institutionalising of the seven green corridors took shape. The first statutory regional plan was published in 1966. Based on a technical study from 1960, a system of seven green corridors in north-south direction was granted a formal status (Zepp, 2018). In this period, industrialisation was still ongoing, although first signs of crisis became visible (with the closure of mines, restructuring of steel mills). Apart from air pollution and water sanitation, the protection of existing green spaces was the main element of regional environmental policies. This rationale changed in the late 1980s when the revitalisation of industrial brownfields and the river system became one of the main relevancies in the process of transformation of the postindustrial region. 


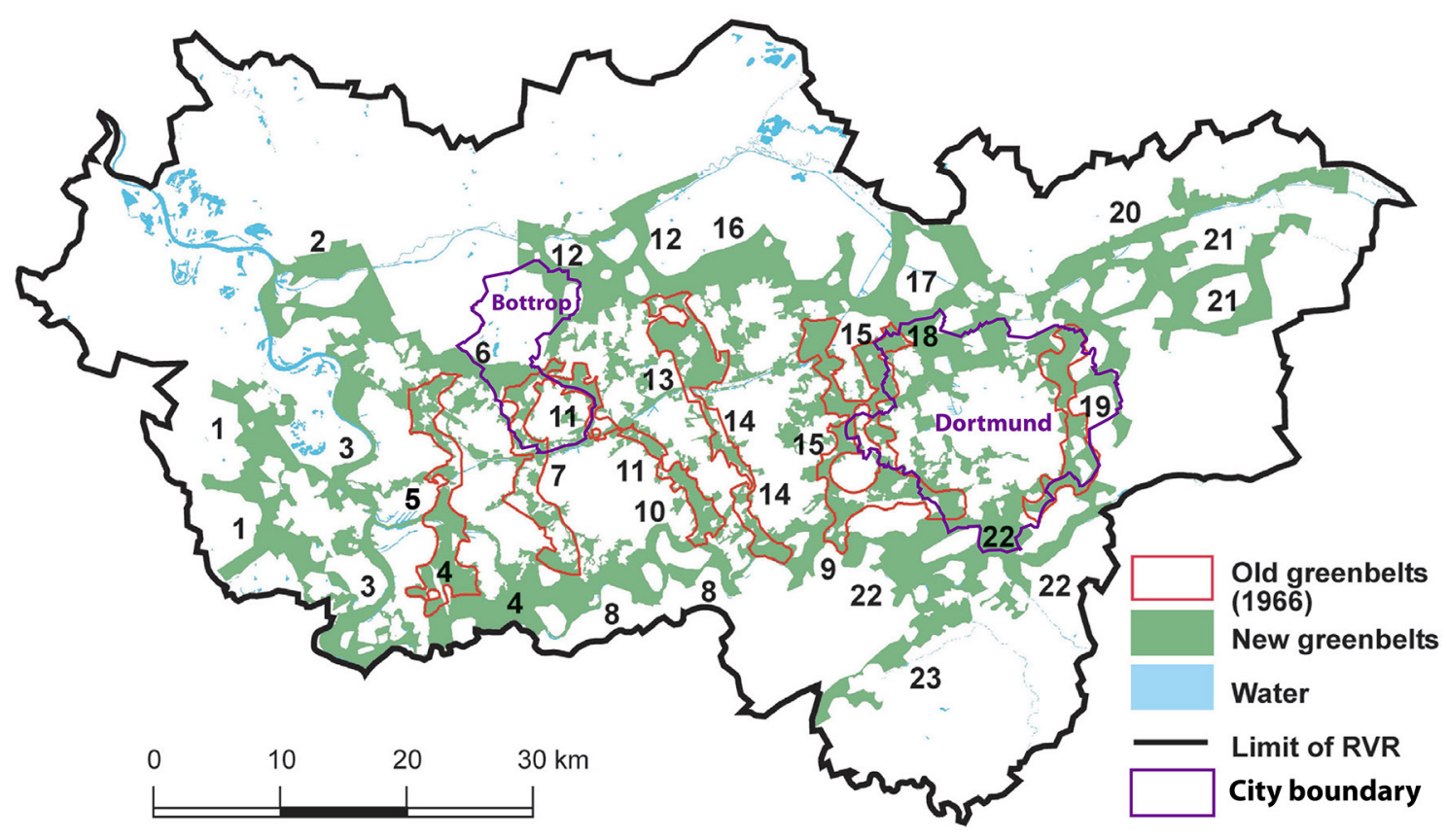

FIGURE 2 | Greenbelts in the Ruhr (modified from source: Zepp, 2018, 7).

A widely acknowledged regional initiative was the International Building Exhibition Emscher Park that was launched in 1989 (IBA-Emscher Park). The IBA was a 10-year intervention with the ultimate goal of transforming the region in many dimensions (economically, environmentally, culturally, and urban design). Hence, protection of existing green spaces was no longer the main driver but was combined with (if not replaced by) regeneration and transformation of no longer used industrial sites and the revitalisation of the river system. The creation of a regional system of green spaces with major land marks, heaps re-designed as tourist attractions, urban wilderness and industrial forests (as a result of succession on industrial waste land), parks, and bicycle paths were the main design elements. Often, this was done in combination with new settlements and the creation of office spaces and light industry on reused industrial sites. In fact, "working in the park" was one of the slogans of the IBA Emscher Park. Many of the ecological and environmental improvements in the period of 1990 until 2014 were financed by the Emscher-Lippe Ecology Programme (co-financed by the European Commission's programme to support former coal fields and industrial transformation). Note that the IBA was an initiative of the state government of North Rhine-Westphalia which met scepticism of the municipalities and counties as the state government used a state led agency in order to secure the implementation of the programme.

From the 2000s onwards, the strategy changed again and this became visible in the master plan Emscher Park (Projekt Ruhr $\mathrm{GmbH}, 2005)$. On the one hand, the green belts of 1966 shrunk significantly in the dense urban environments of the industrial core because of the extension of commercial developments and transport infrastructures (Zepp, 2018, Figure 2). The provision of green spaces in the Ruhr turned out to be comparatively low (Dosch and Porsche, 2008). As a result of this loss of open green spaces, environmental quality and access to green spaces in some of the cities was precarious (Dosch and Porsche, 2008). The main purpose of the master plan Emscher Park was to stop this loss of green infrastructure, to extend the system of green corridors and to improve the quality of existing green spaces in cities (Projekt Ruhr GmbH, 2005; Zepp, 2020). Again, it was the state government of North Rhine-Westphalia that supported the master plan. In fact, the Project Ruhr Agency, being in charge of elaborating the master plan, was an agency paid by the state government in order to continue with some of the initiatives of the IBA Emscher Park. Since 2004 the regional planning authority (Regionalverband Ruhr) is in charge of the Emscher Landscape Park. It owns quite a lot of the land (forests in particular) and is responsible for the maintenance and further development of the park. This task, however, needs close collaboration with the municipalities and the Emscher Association.

As a result of the regional park policy and the implementation of the master plan, in terms of numbers, the increase of green infrastructure in the Ruhr region was $137 \mathrm{~km}^{2}$ so that the new territory of the Emscher Landscape Park is a total of $457 \mathrm{~km}^{2}$ (Projekt Ruhr GmbH, 2005). This increase happened largely at the fringes while the situation in the inner parts of the city-region is still problematic (Figure 2). Besides the green corridors in north-south direction there is a new green corridor in east-west 
direction. It is called the new Emscher Valley and existed more or less before but receives increased attention as this corridor coincides with the river Emscher (Emschergenossenschaft, 2006). The Emscher regeneration is another element in the green space strategy of the Ruhr and its current implementation is defined in the masterplan Emscher Revitalisation (Emscher Umbau) (Emschergenossenschaft, 2006). Although its main purpose is the regeneration and re-naturalisation of a degraded and polluted river system there is a significant spatial and functional overlap with the green infrastructure strategy of the regional planning authority RVR (Regionalverband Ruhr/RVR, 2016; Zepp, 2020). Hence, today the two regional associations (regional planning authority + Emscher Association) have taken over the leadership while the direct influence of the state government is now limited to funding (channelling also EU funds in the direction of green infrastructure).

This initiative is also a result of the change of the debate on green infrastructure and nature-based solutions. The rather new emphasis on ecosystem services makes the overall contribution of urban green for human well-being clear as it gives a monetary value to green spaces. The societal benefits of ecosystem services increased the relevance and allowed for the estimation of the monetary impact of loss of green spaces. Recent policy documents show a high commitment to the economic benefits of green infrastructures (Regionalverband Ruhr/RVR, 2016).

Although the master plans and policy documents of the regional planning authority RVR and the Emscher Association indicate an extension and qualification of green infrastructure, there is also criticism. This criticism refers to a significant loss of green spaces in specific areas so that the accessibility to green infrastructure is low for some segments of the residential population. Criticism was also made with regard to the quality. The green corridors are not nicely designed landscapes and parks, at least not everywhere. There are isolated buildings, power lines, agrarian land, roads, etc. (Regionalverband Ruhr/RVR, 2015; Zepp, 2018; Zepp et al., 2020, p. 81). The extension of the green corridors was planned in the east-west as well in the north-south direction but as a result of the losses the concept is now split up into 23 elements (the seven corridors are still visible but some of them are fragments, Figure 2). There is also a significant difference with regard to the size and coherence in the subregions. While in the east of the Ruhr (surroundings of Dortmund) we find large connected parts of forests and agricultural land, in the mid-west the structure of the green corridor is rather fragmentary and the lots are on average smaller.

While the uneven distribution of green infrastructure in terms of size and quality did result only in low levels of politicisation, the preparation of the new statutory regional plan in 2019 opened the ground for some controversies. While the plan proposal clearly accentuated the functional relevance of the green corridors, some municipalities were asking for more zones for commercial development and due to partial treatment of subareas and cities conflicts of land use are likely to emerge (Regionalverband Ruhr/RVR, 2015). This makes clear that there is gap between the overall acceptance of a regional green infrastructure strategy and the articulation of interests in some cities and municipalities.

It needs to be stated that the green infrastructure strategy is also not primarily thought to balance the unequal provision of high-quality green spaces for the citizens. It is rather a mix of attracting tourists and increasing the overall attractiveness of the region. Reimer and Rusche (2019) stress that the essential element of landscape planning in the Ruhr is an event-led strategy or festivalisation. The creation of land marks, the use of events such as cultural capital of Europe in 2010 or the planned international garden exhibition (in 2027) are the main building blocks of this strategy. Green infrastructure is not considered as being part of a territorial politics of welfare and we can also say that green infrastructure provision is not a result of bottomup processes but rather led by the regional associations and local governments in connection with incentives given by the state government and the European Commission. This situation contrasts with scholarly descriptions of civic movements having a strong influence on green infrastructure initiatives (Agyeman and Evans, 2004). This is not the case in the Ruhr region.

The two cities of Dortmund and Bottrop benefitted from the regional green infrastructure strategy and the investment into the Emscher Landscape Park. However, the location of these two cities demonstrates the variation of green infrastructure development in the city-region. Bottrop is situated in the core of the industrial zone with dense industrial areas in the south just next to the river Emscher. So far only a few projects in this area have been implemented but the Masterplan Emscher Landscape Park foresees interventions here (Wellheimer Mark) (Projekt Ruhr GmbH, 2005). The transformation of these areas in the south of Bottrop is under way (see below and Figure 4).

Dortmund developed a large area in the south in the 2000s. The area of the former steel mill Phoenix has been transformed into a residential zone with an artificial lake of 24 ha and highquality housing (Frank, 2021). The lake is part of the Emscher Landscape Park and also used as a rain water retention facility. The implementation provoked discussion on the reasonableness of this investment. Although the transformation of the area, that was once said to be the dirtiest place of the Ruhr, showed significant improvement in terms of landscape quality and environmental condition, the Lake Phoenix project created a very peculiar social situation as upper-middle class houses and villas were placed next to an old working-class neighbourhood. A citywide discourse on gentrification emerged but until today there is a lack of accurate data. Certainly, the neighbourhood changed a lot but residents evaluate the process not totally negative as they see the benefits of the upgrade of the area (including the rise of house values) (Frank, 2021). As we will show later, the need for a green intervention is much higher in the northern parts of the city. In any case, the Lake Phoenix project, being part of the Emscher regeneration scheme, displays the ambivalence and selectivity of green infrastructure interventions. The following two sections will introduce an environmental justice analysis for the two cities of Bottrop and Dortmund in order to demonstrate that, despite the above-mentioned interventions, a lack of green infrastructure is still an issue. 
TABLE 1 | Indicators used for environmental justice analysis.

\begin{tabular}{|c|c|c|c|}
\hline Category & Indicator [acronym] & Definition & Threshold [>0.5 normalised value] \\
\hline \multirow[t]{2}{*}{ Environmental benefit } & $\begin{array}{l}\text { Supply of public green and } \\
\text { open space [GSup] }\end{array}$ & $\begin{array}{l}\text { Size of public green and open space } \\
\text { per inhabitant }\end{array}$ & $\begin{array}{l}<6 \mathrm{~m}^{2} \text { of public green and open space per } \\
\text { inhabitant within a statistical district }\end{array}$ \\
\hline & $\begin{array}{l}\text { Accessibility of public green } \\
\text { and open space [GAcc] }\end{array}$ & $\begin{array}{l}\text { Percentage of inhabitant living near } \\
\text { public green and open space }\end{array}$ & $\begin{array}{l}<50 \% \text { of residents per district who have } \\
\text { access to public green and open space } \\
\text { within a distance of } 500 \mathrm{~m} \text { (for } \geq 1 \text { ha } \\
\text { spaces) and } 1,000 \mathrm{~m} \text { (for } \geq 10 \text { ha spaces }\end{array}$ \\
\hline \multirow[t]{3}{*}{ Environmental burden } & Noise pollution [NOI] & $\begin{array}{l}\text { Percentage of area having a noise } \\
\text { impact }\end{array}$ & $\begin{array}{l}>50 \% \text { of statistical district area covered } \\
\text { by }>55 \mathrm{db}(\mathrm{A}) \text { LDEN }\end{array}$ \\
\hline & $\mathrm{PM}_{10} / \mathrm{PM}_{2,5}$ pollution [PM] & $\begin{array}{l}\text { Percentage of area having emission } \\
\text { of } \mathrm{PM}_{2,5}, \mathrm{PM}_{10}\end{array}$ & $\begin{array}{l}>50 \% \text { of statistical district area covered } \\
\text { by }>78 \mathrm{~kg} / \mathrm{a}\end{array}$ \\
\hline & $\mathrm{NO}_{\mathrm{x}}$ pollution $\left[\mathrm{NO}_{\mathrm{x}}\right]$ & $\begin{array}{l}\text { Percentage of area having emission } \\
\text { of } \mathrm{NO}, \mathrm{NO}_{2}\end{array}$ & $\begin{array}{l}>50 \% \text { of statistical district area covered } \\
\text { by }>700 \mathrm{~kg} / \mathrm{a}\end{array}$ \\
\hline \multirow[t]{3}{*}{ Climate-related extreme event } & Hot days [HD] & $\begin{array}{l}\text { Number of days whose temperature } \\
\text { is above } 30^{\circ} \mathrm{C}\end{array}$ & $>11$ hot days per statistical district \\
\hline & Tropical nights [TN] & $\begin{array}{l}\text { Number of days whose temperature } \\
\text { is above } 20^{\circ} \mathrm{C}\end{array}$ & $>2.4$ tropical nights per statistical district \\
\hline & Flood risk [Fld] & $\begin{array}{l}\text { Percentage of residential area, mixed } \\
\text { use area, and area with critical social } \\
\text { infrastructure that are at risk of } \\
\text { flooding }\end{array}$ & $\begin{array}{l}>50 \% \text { of flooded residential area, mixed } \\
\text { used area, and area with critical social } \\
\text { infrastructure on a flooding with a return } \\
\text { period of more than } 500 \text { years per } \\
\text { statistical district }\end{array}$ \\
\hline Socio-economic status & $\begin{array}{l}\text { SGB II and SGB XII recipient } \\
\text { [SGB II/XII] }\end{array}$ & $\begin{array}{l}\text { Percentage of SGB II and SGB XII } \\
\text { recipient }\end{array}$ & - \\
\hline
\end{tabular}

\section{METHODOLOGY}

The data used in this paper were gathered from Bottrop and Dortmund-two cities in the Ruhr region that differ in size. The territory of both cities is part of the Emscher River system and hence both cities are beneficiaries of the Emscher Landscape Park and the Emscher regeneration process. Bottrop and Dortmund are obligatory members of the regional planning authority and the Emscher Association and both mayors have taken leading roles in these organisations. Hence, both cities are part of a multi-level governance arrangement that they share with several other cities, towns and counties. Bottrop is situated in the north-western part of the Ruhr region. It covers nearly $101 \mathrm{~km}^{2}$ with a population of 117,000 inhabitants. Bottrop has meadows and agricultural land in the northern and central part as well as a large forest area in the western part. The southern part of the city is densely populated and urbanised (with a harbour, coal depots, former mining areas, and a coking plant). Dortmund, which is located in the eastern part of the Ruhr region, covers $280 \mathrm{~km}^{2}$ and is home to 600,000 inhabitants. As part of the Ruhr region, Bottrop and Dortmund share the history of coal mining and steel production, thus have been undergoing a long-lasting transformation. Like other cities in the Ruhr region, Bottrop and Dortmund are increasingly exposed to climate-related extreme events such as heat waves, heavy rainfalls and flooding. For example, heavy rain in 2008 reached the highest intensity measured so far in Dortmund, and led to the overflow of a rain water retention basin in Dortmund-Marten with remarkable damages. Likewise, storm Ela in 2014 and Elvira in 2016 caused enormous damage on cities.
Environmental justice analysis was carried out for Bottrop and Dortmund in order to figure out how, among others, sufficient and accessible green infrastructure is in both cities and whether there is an environmental inequality. A broad set of geodata was used, largely from the existing open geodatabases of North Rhine-Westphalia. Altogether nine core indicators were established in four categories, i.e., environmental benefit, environmental burden, climate-related extreme event, and socioeconomic status (see Table 1). The analysis involved several steps. First, indicators were selected based on the precedent studies and the availability of data in the existing database. After indicators were quantified by setting adequate thresholds, Bottrop and Dortmund were spatially analysed at the statistical district level based on each indicator. The analysis was carried out using ArcGIS 10.4 software and its Network Analyst extension. The results passed through a Boolean overlay and were finally visualised in a multiple-load map. Throughout the process, local stakeholders were involved via living labs in order to discuss interim results and optimise the process. It was an iterative process with learning effects for both the scientific and practical side. In the following, each indicator used for the analysis is explained.

As mentioned in the acknowledgment Kristina Ohlmeyer, Mathias Schaefer, Madeleine Kirstein, Dietwald Gruehn, and Stefan Greiving conceptualised and conducted the environmental justice analysis for Bottrop and Dortmund (Bakunowitsch et al., 2019; Ohlmeyer et al., 2021, 91-145).

Environmental benefit takes into account two indicators, i.e., supply as well as accessibility of public green and open space. When it comes to the supply side, the size of public green and open space per inhabitant is the determining factor. The actual 
situation was compared by referring to a value proposed by the Deutscher Städtetag (German Association of Cities) in Berlin, namely $6 \mathrm{~m}^{2} /$ person (SenUVK, 2017). The ultimate goal was to find out if there was an oversupply or shortage in the provision of public green and open space. Concerning accessibility, public green, and open spaces were first divided into two categories: (1) those larger than or equal to one hectare but $<10$ ha; and (2) those larger than or equal to $10 \mathrm{ha}$. The distance thresholds for each category were set at 500 and $1,000 \mathrm{~m}$, assuming that larger spaces imply a higher degree of centrality to visitors. Next category is environmental burden consisting of three indicators related to noise and air pollution. Noise is the result of a variety of sources, each with a varied duration and intensity. For this analysis, all noise pollution isotopes were combined and the spatial share of noise isotopes per statistical district was calculated using intersection processes. Concerning air pollution, the percentage area per statistical district was calculated by using the $1 \times 1 \mathrm{~km}$ emission raster.

Another category is climate-related extreme events; it includes hot days, tropical nights and flood risk. A mean value was determined for each statistical unit using vector data of hot days and tropical nights from 1989 to 2010. The flood hazard mapping gave crucial information on the spatial scope of a potential flooding event. The percentage of residential area, mixed use area, and area with critical social infrastructure that are at risk of flooding was calculated for each statistical district. Lastly, the percentage of welfare recipient is used as an indicator for the category of socio-economic status. Percentage of SGB II and SGB XII recipient was calculated for each statistical district. Since the availability and accessibility of social and health data is rather limited, partly due to the data privacy, diversity of indicator is not achieved.

\section{FINDINGS}

Bottrop and Dortmund were spatially analysed based on the selected indicators at statistical district level. The result was first presented separately for each indicator (see Figures 3, 5). Then they were overlaid and presented in a multiple-load map (see Figures 4, 6).

Figure 3 shows the result of spatial analysis for each indicator in Bottrop. First, deficits regarding the supply of public green and open space [GSup] are present in the north and south of the city. Accessibility [GAcc] is high across the city due to the overall high proportion of public green and open space in Bottrop. The map for noise pollution [NOI] reveals that there is high noise pollution around superordinate roads and motorways. Air pollution [NOx, $\mathrm{PM}]$ is especially high in the south of the city where industrial plants are agglomerated. Also, there are isolated cases in the north where the A2 and A31 highways are. Concerning climaterelated extreme events, the southern part of the city, and in particular within and around the old town, is characterised by a high number of hot days [HD] and tropical nights [TN]. What is more, high proportion of residential area, mixed use area and area with critical infrastructure in the south are affected by flood events [Fld] with a return period of 500 years. This is due to the proximity to the Emscher river. Lastly, there is a high proportion of welfare recipient [SGB II/XII] in the south of the city.

The multiple-load map of Bottrop (Figure 4) shows multiplestressed areas in Bottrop. According to the analysis, there are more multiple-stressed areas in the south compared to the north. Indeed, 5-7 times stressed districts are concentrated in the south, close to the river Emscher. This can be partly explained by the fact that the south is densely populated and has many industrial sites (including a coking plant and former mining sites) and is crossed by railway lines and a highway. The result shows that this is also where high proportion of welfare recipient resides. Finally, a correlation analysis was conducted using the SPSS statistical program in order to determine whether there is a correlation between (1) the supply of public green and open space and the share of social welfare recipient; and (2) environmental stresses and the share of social welfare recipient. Spearman's rank correlation was used. Significance level was defined $\alpha$ $=0.05$. Furthermore, the data set was limited to inhabited areas. A significant negative weak correlation $(r=-0.266)$ was found between the supply of public green and open space and the proportion of welfare recipient with $8 \%$ the explanatory power. In contrast, a significant positive moderate correlation $(r=0.508)$ was found between environmental stresses and the proportion of welfare recipient with $26 \%$ explanatory power (Bakunowitsch et al., 2019).

Figure 4 also shows the areas of intervention that have been initiated so far (planning started in 2018). The red dotted line indicates the area of the cross-municipal development zone and the intervention of the Emscher Masterplan. The project is called "Emscher Freiheit" (Emscher Freedom), a business zone on a former industrial site that is planned in cooperation with the neighbouring city of Essen with high proportions of green space. Another recent intervention is the requalification and extension of a park in this neighbourhood ("Wellheimer Lückenschluss," i.e., connecting interrupted green corridors). A coking plant still is active in this neighbourhood. Although meeting the standards of EU environmental legislation, air pollution is an issue here. The map also shows the inner-city green belts. The blue line demarcates an area where initiatives to increase the energy efficiency of buildings have been taken (called "Innovation City").

Figure 5 shows the result of spatial analysis for each indicator in Dortmund. First, deficits concerning the supply of public green and open space [GSup] are mainly found in central part of the city. Accessibility [GAcc] is very high in almost all statistical districts except for the city centre. In fact, $91 \%$ of residents live in average 300/700 $\mathrm{m}$ away from the next public green and open spaces. The map for noise pollution [NOI] shows that there is high noise pollution around superordinate roads and motorways. Air pollution $\left[\mathrm{NO}_{\mathrm{x}}, \mathrm{PM}\right]$ is concentrated mainly in the central part of Dortmund. Regarding climate-related extreme events, and in particular a number of hot days [HD] and tropical nights [TN], the central area reveals to be relatively higher than other parts of the city. In terms of flood events [Fld], western part of the city has a risk to be affected. Lastly, there is a high proportion of welfare recipients [SGB II/XII] in the central and northern part of the city. 
A GSup

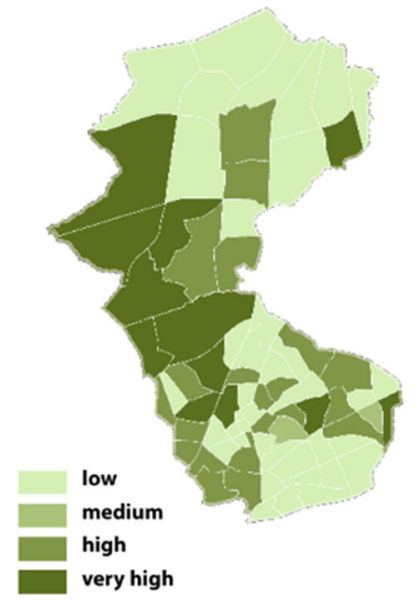

D NOx

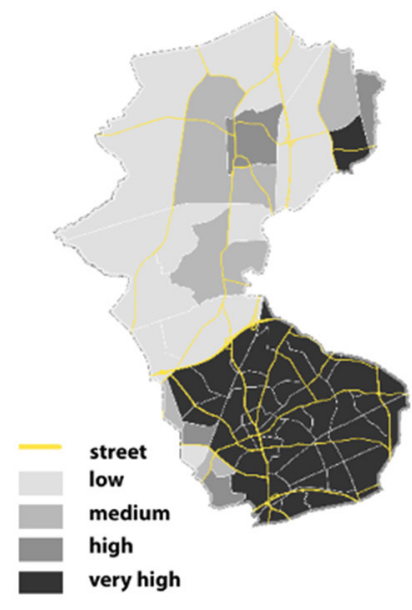

G TN

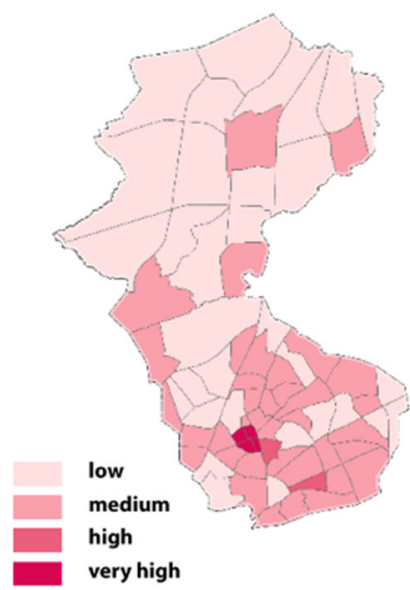

B GAcc

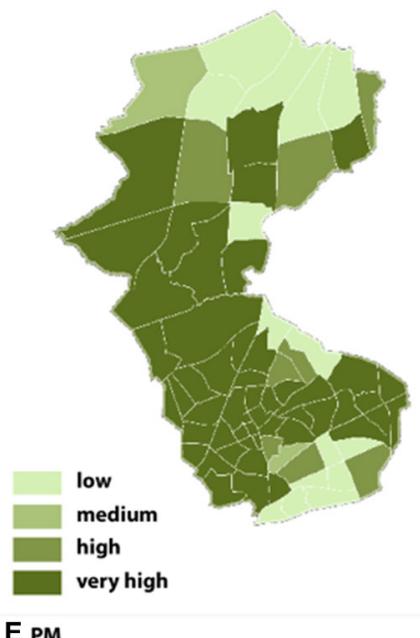

E PM

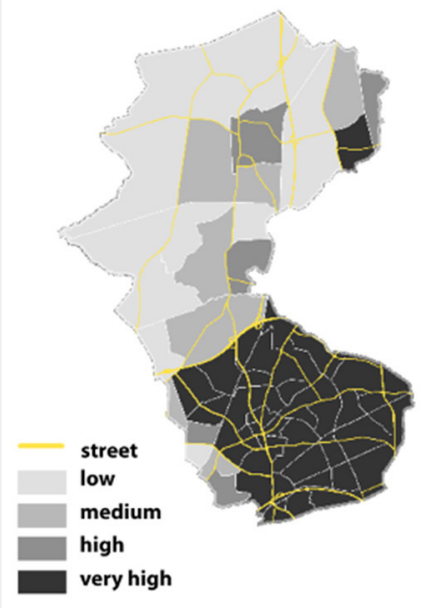

H Fld

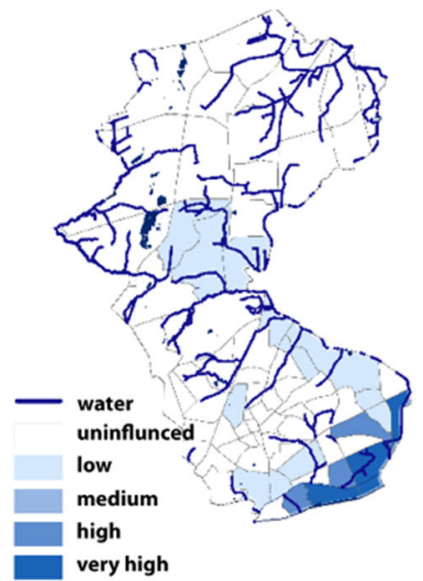

C NOI

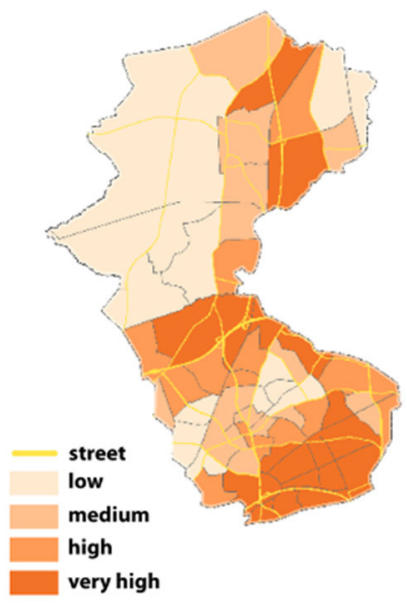

F HD

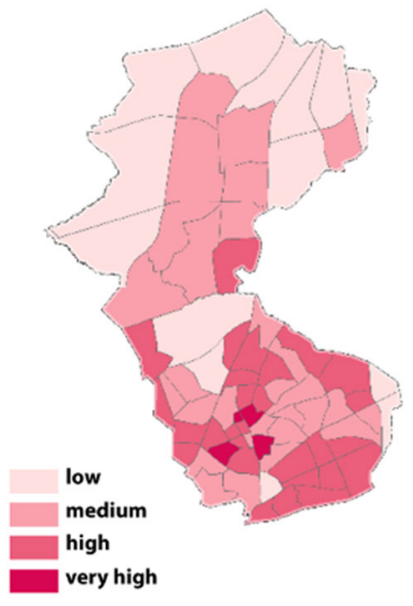

| SGB II/XII (\%)

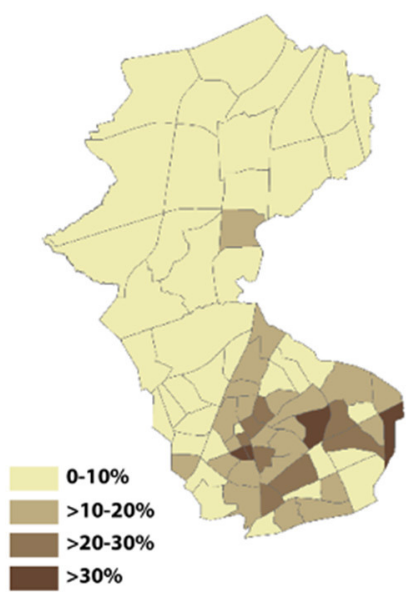

FIGURE 3 | Result of spatial analysis for each indicator (Bottrop) (source: Bakunowitsch et al., 2019, 120). 


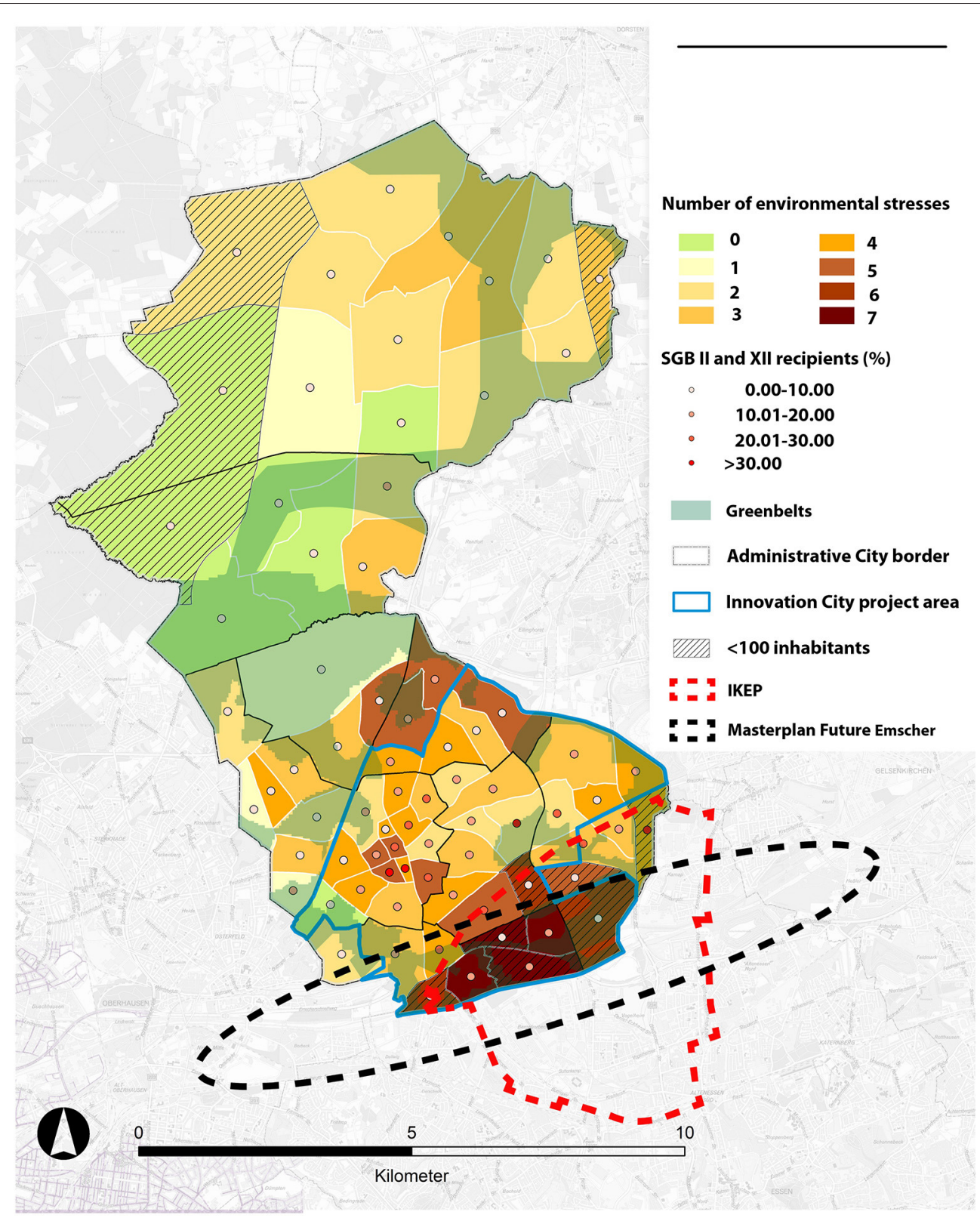

FIGURE 4 | Multiple-load map for Bottrop (modified from source: Bakunowitsch et al., 2019, 117).

The multiple-load map of Dortmund (Figure 6) shows multiple-stressed areas in Dortmund. According to it, there are multiple-stressed areas in the central part of the city. Five to six times stressed districts are concentrated in the area. As the result shows, this is also where high proportion of welfare recipient live. For Dortmund, a correlation analysis was conducted as well to determine whether there is a correlation between (1) the supply of public green and open space and the share of social welfare recipient; and (2) environmental stresses and the share of social welfare recipient. A significant negative weak correlation $(r=-0.239)$ was found between the supply of public green and open space and the proportion of welfare recipient with $6 \%$ explanatory power. In contrast, a significant positive moderate correlation $(r=0.44)$ was found between environmental stresses and the proportion of welfare recipient with 20\% explanatory power (Bakunowitsch et al., 2019).

All in all, the environmental justice analysis carried out in Bottrop and Dortmund reveals that, in both cities, there is environmental inequality as evidenced by a negative correlation between the supply of public green and open space and the share of social welfare recipient as well as a positive correlation between the environmental stresses and the share of social welfare recipient. The result of spatial analysis for environmental benefit shows that the accessibility to public open and green 
A GSup
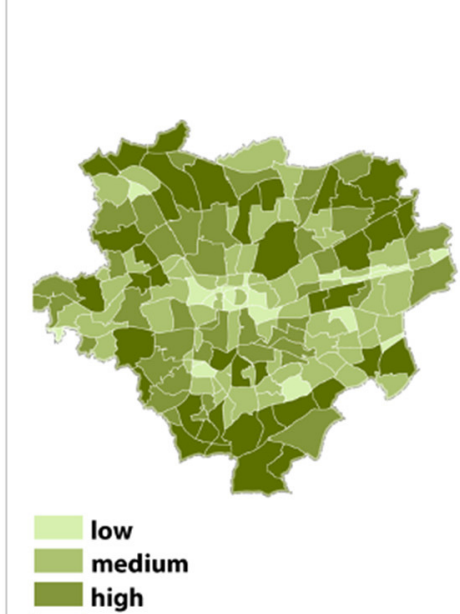

high

very high

D NOx

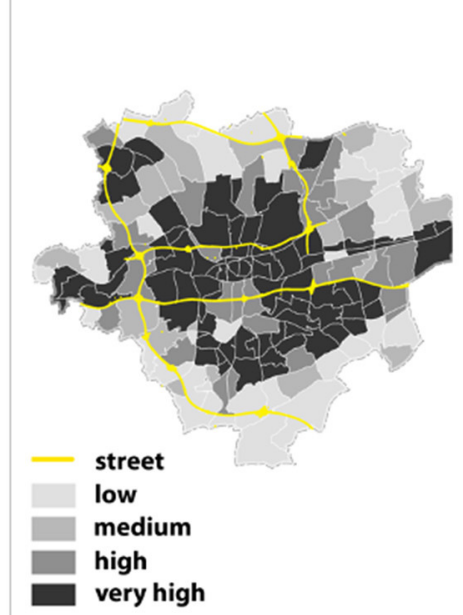

G TN

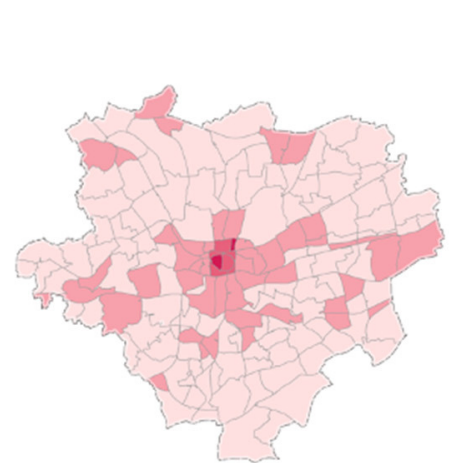

low

medium

high

very high
B GACC

C NOI

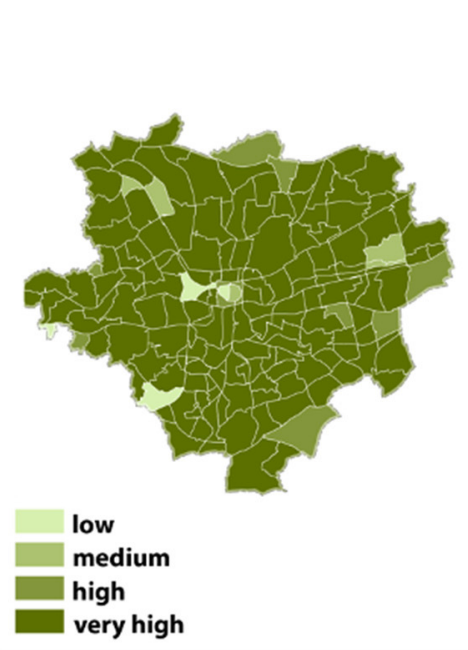

E PM

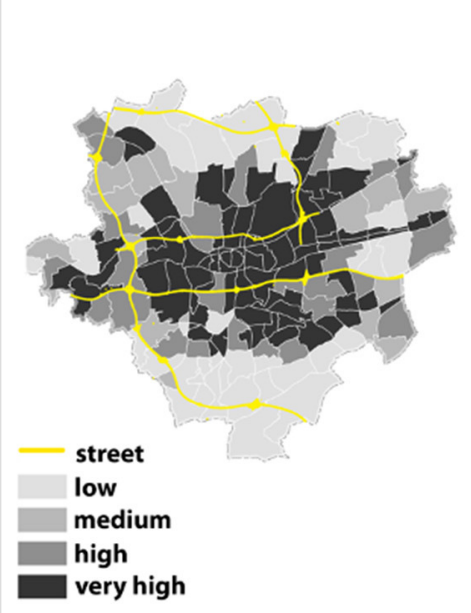

H Fld

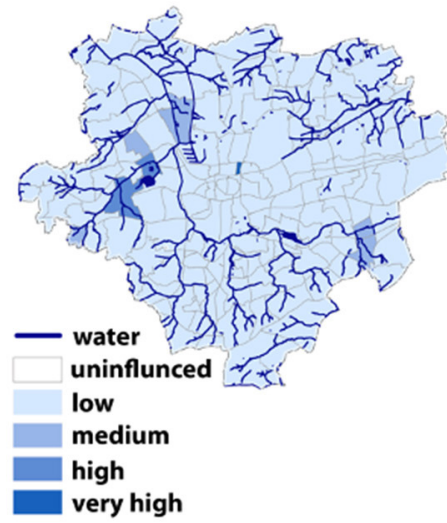

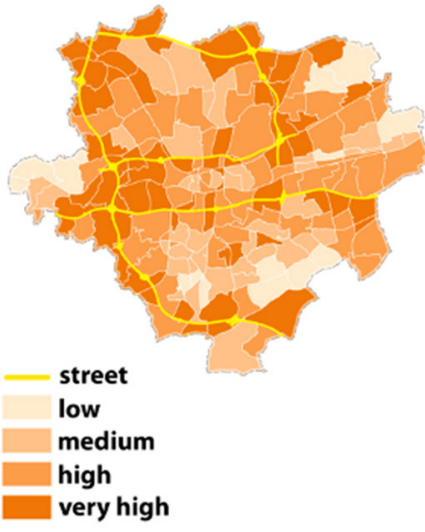

F HD

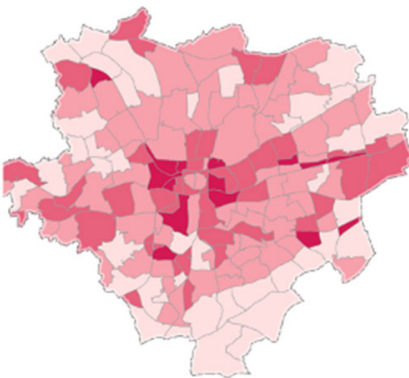

low

medium

high

very high

I SGB II/XII (\%)

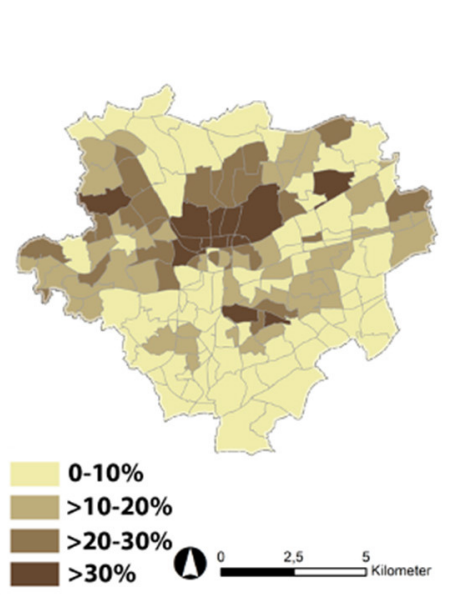

FIGURE 5 | Result of spatial analysis for each indicator (Dortmund) (source: Bakunowitsch et al., 2019, 124). 


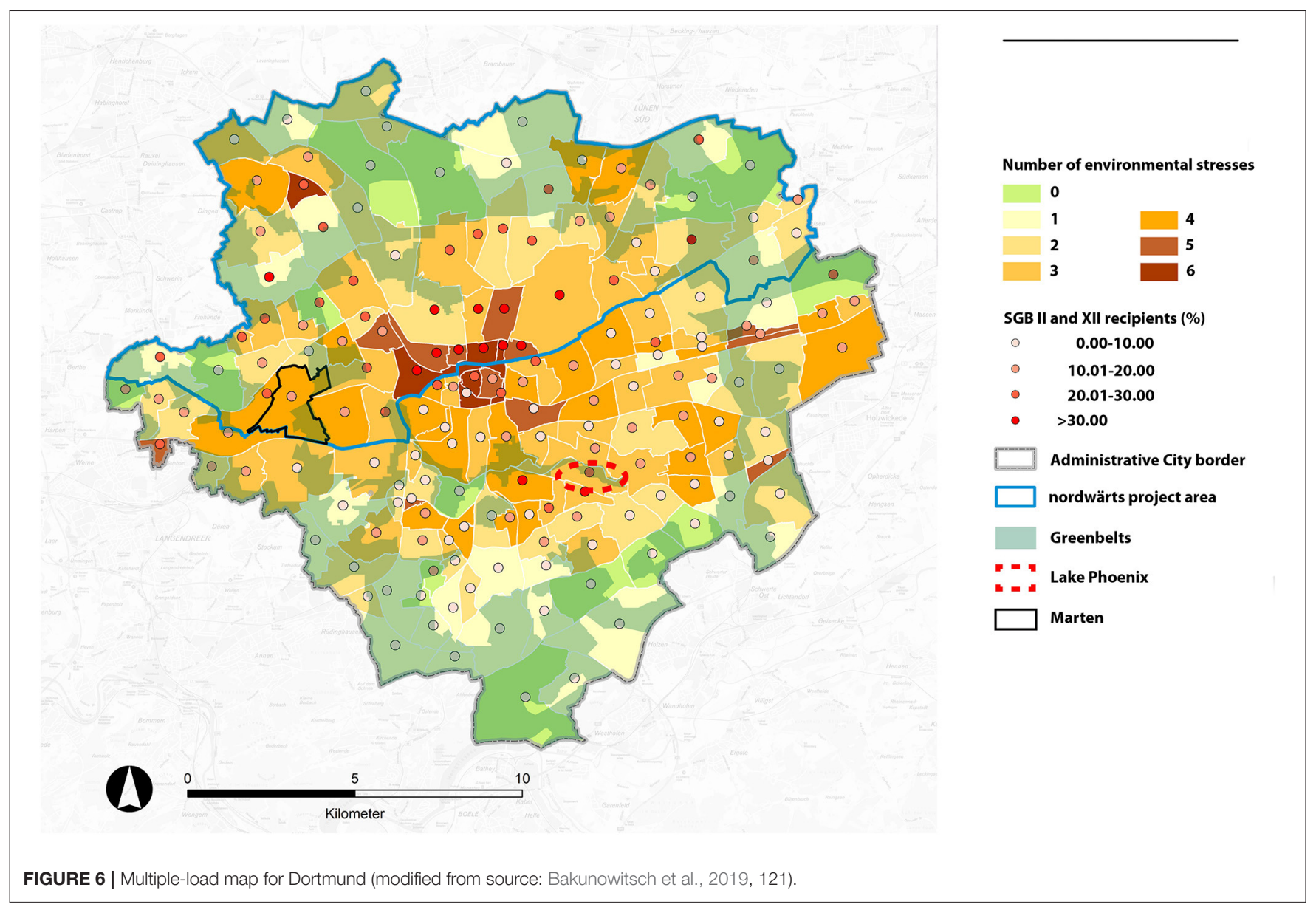

space in both cities is less an issue, whereas its supply varies considerably across the cities. While on the regional scale, the investments made in the Emscher zone can be seen as a trial to balance and repair a long-standing unequal provision with environmental qualities, on a smaller scale (i.e., cities and neighbourhoods) we can demonstrate that in the cities of the Emscher zone environmental inequality is still observable. The Emscher revitalisation programme and the Emscher Landscape Park had some beneficial effects for some municipalities but by far not for all. Some neighbourhoods benefit stronger from investment in regional parks and green infrastructure than others. What seems to be green region shows environmental injustice on a smaller scale in cities and neighbourhoods.

\section{DISCUSSION AND CONCLUSION}

This paper examined to what extent green infrastructure planned at the regional level can contribute to environmental justice within a city-region. Without a doubt, regional planning for green infrastructure is well established in the Ruhr. The process started in the 1920s, became part of statutory regional planning in the 1960s, found strong operational support of the state government in the 1990s and early 2000s and is now in the hands of to two regional associations that share the characteristic of inter-municipal membership. However, analysis of data by Zepp (2018) demonstrates that the old green corridors of 1966 have shrunk significantly in the core zone of the Ruhr (see also Regionalverband Ruhr/RVR, 2015). The extension of the green corridors at the fringes of the city-region does not compensate for this loss from an environmental justice perspective. In addition, our quantitative research on city level revealed that there is a direct correlation between the supply of and accessibility to green infrastructure and environmental justice. Yet, the Emscher Park interventions did not intervene in these areas or began to do so only recently (i.e., in the south of Bottrop). It seems that advocacy for green infrastructure on the regional level is not enough to secure environmental justice on a smaller scale.

At the same time, investments in green infrastructures are made for many reasons and environmental justice does not seem to be the most important one. Functions that found strong recognition are water retention, flood control, eco system services (biodiversity), climate adaptation (fresh air circulation), recreation, and control of land consumption. Only recently guidance and policy documents proclaim that the park will be brought closer to the citizens (Regionalverband Ruhr/RVR, 2019, 2015). In fact, recent planning documents indicate that this 
weakness of the regional approaches will be tackled. RVR as well as Emscher Association discovered this weakness and proclaimed to go into the cities. The city administration of Bottrop did go even a step further and now employs a "climate justice manager" in the planning department. She is in charge of the green infrastructure projects in the south of the city. The Emscher regeneration programme and the detailed insights into two cities of the Ruhr suggest that green infrastructure should be planned not only at the regional but also at the smaller scale (i.e., cities and neighbourhoods). Hence, we argue that environmental justice is a question of scale, also in terms of politicisation. While it is highly valuable to give an emphasis to green infrastructure as an amenity of regional relevance with respective lighthouse projects (such as Lake Phoenix and other landmarks), we demonstrated the need to think green infrastructure as a coherent network from the regional level, to the city and the quarter. Actors from different disciplines must work together with the aim of developing and maintaining green infrastructure across all scales. Accessibility and quality differ a lot due to the unbalanced provision of green space. There is a need for a multi-scaled governance approach for green infrastructure. In terms of institutional design for environmental justice, this implies a stronger coupling of regional and local initiatives.

With regard to the conception of environmental justice the implications are significant. As Moroni points out (2020), there is a variety of ways of how to define justice. In the debate on environmental justice a focus on distributive justice is very influential as many studies show empirically the unequal distribution of green amenities and/or environmental burdens. This assumes that environmental quality is a scarce good that provokes conflicts of distribution and access. We would like to add the perspective of institutional justice as green infrastructure strategies clearly are the result of a specific governance regime. As Moroni puts it:

"It is the basic urban institutional framework which must satisfy criteria of justice. Considered in these terms, if we speak, for example, of the injustice of certain urban situations-for example, the state of certain peripheral neighbourhoods or the inaccessibility of certain basic urban services-we are actually assuming implicitly that what is unjust in reality are the urban

\section{REFERENCES}

Agyeman, J., and Evans, B. (2004). 'Just sustainability': the emerging discourse of environmental justice in Britain? Geogr. J. 170, 155-164. doi: 10.1111/j.0016-7398.2004.00117.x

Bakunowitsch, J., Davy, B., Frank, S., Fuchs, M., Greiving, S., Gruehn, D., et al. (2019). “Analyse der zentralen sozial-ökologischen Herausforderungen auf den Ebenen Quartier (Dortmund-Marten); Stadt (Bottrop) und Region (RVR),” in Ein Arbeitspapier aus dem ZUKUR-Projekt - Chapter 4 Umweltgerechtigkeit (Dortmund), 91-145.

Benedict, M., and McMahon, E. (2002). Green infrastructure: smart conservation for the 21st century. Renew. Resour. J. 20, 12-17.

Black Congressional Caucus (2004). African Americans and Climate Change: An Unequal Burden. Congressional Black Caucus Foundation.

Bullard, R. (1996). Symposium: the legacy of American apartheid and environmental racism. St. Johns J. Legal Comment 9, 445-474. institutions that have allowed such situations to arise and do not intervene in order to right them" (Moroni, 2020, 254).

This applies to the local as well as to the city-regional dimension. Many of the positive results of green infrastructure development in the Ruhr region are the result of institutional design that goes back to the period of the industrialisation (i.e., the creation of regional associations) or the implementation of the post-war planning system (1966). The intervention of the state government in 2003-2005 was also an important step (Masterplan Emscher Landscape Park). The strong position of local governments in Germany, however, sometimes poses a threat to this city-regional policy.

\section{DATA AVAILABILITY STATEMENT}

The raw data supporting the conclusions of this article will be made available by the authors, without undue reservation.

\section{AUTHOR CONTRIBUTIONS}

All authors listed have made a substantial, direct and intellectual contribution to the work and approved it for publication.

\section{FUNDING}

This study was financed by German Federal Ministry of Education and Research/ BMBF (grant number 01LR1721A).

\section{ACKNOWLEDGMENTS}

Special thanks to Kristina Ohlmeyer, Mathias Schaefer, Madeleine Kirstein, Dietwald Gruehn, and Stefan Greiving for conceptualising and conducting the environmental justice analysis for Bottrop and Dortmund. The analysis was done in Working Package 3 as part of the research project ZUKUR and its result was invaluable for writing this paper. Their work is published in Ohlmeyer et al. (2021) and Bakunowitsch et al. (2019), 91-145. Prof. Harald Zepp deserves thanks for allowing us to use Figure 2.
Bullard, R. (2000). Dumping in Dixie: Race, Class, and Environmental Quality, 3rd edn. Boulder, CO: Westview.

Bullard, R., and Johnson, G. (2000). Environmental justice: grassroots activism and its impact on public policy decision making. J. Soc. Issues 56, 555-578. doi: 10.1111/0022-4537.00184

Byrne, J., Wolch, J., and Zhang, J. (2009). Planning for environmental justice in an urban national park. J. Environ. Plann. Manag. 52, 365-392. doi: $10.1080 / 09640560802703256$

Chavis, B., and Lee, C. (1987). Toxic Wastes and Race in the United States. New York, NY: United Church Christ.

Curran, W., and Hamilton, T. (2012). Just green enough: contesting environmental gentrification in Greenpoint, Brooklyn. Local Environ. 17, 1027-1042. doi: 10.1080/13549839.2012.729569

De Sousa Silva, C., Viegas, I., Panagopoulos, T., and Bell, S. (2018). Environmental justice in accessibility to green infrastructure in two European cities. Land 7, 134. doi: $10.3390 /$ land 7040134 
Dosch, F., and Porsche, L. (2008). Grüne Potenziale unter blauem Himmel. Neue Zugänge zur Flächenrevitalisierung und Freiraumentwicklung im Ruhrgebiet. Inf. Raumentwicklung Heft. 9/10, 609-625.

Emschergenossenschaft (2006). Masterplan Emscherzukunft (Masterplan Future Emscher). Essen.

EPA (2021). Learn About Environmental Justice. U.S. Environmental Protection Agency. Retrieved from: https://www.epa.gov/environmentaljustice/learnabout-environmental-justice (accessed February 18, 2021).

European Commission (2013). Building a Green Infrastructure for Europe. Luxemburg: European Commission.

Frank, S. (2021). Gentrification and neighborhood melancholy. Collective sadness and ambivalence in Dortmund's Hörde district. Cult. Geogr. 28, 1-15. doi: 10.1177/1474474020987253

Gill, S., Handley, J., Ennos, A., and Pauleit, S. (2007). Adapting cities for climate change: the role of the green infrastructure. Built Environ. 33, 115-133. doi: 10.2148 /benv.33.1.115

Gould, K., and Lewis, T. (2017). Green Gentrification: Urban Sustainability and the Struggle for Environmental Justice. New York, NY: Routledge.

Irazábal, C. (2021). "Governance, institutional coordination, and socio-spatial justice: reflections from Latin America and the Caribbean," in Resilient Urban Regeneration in Informal Settlements in the Tropics. Advances in 21st Century Human Settlements, ed. O. Carracedo García-Villalba (Cham: Springer), 151-173.

Keil, R., and Debbané, A.-M. (2005). Scaling discourse analysis: experiences from Hermanus, South Africa and Walvis Bay, Namibia. J. Environ. Policy Plann.7, 257-276. doi: 10.1080/15239080500339786

Köckler, H. (2017). Umweltbezogene Gerechtigkeit - Anforderungen an eine zukunftsweisende Stadtplanung. Frankfurt am Main: Verlag Peter Lang.

Mohai, P., Pellow, D., and Roberts, J. (2009). Environmental justice. Annu. Rev. Environ. Resour. 34, 405-430. doi: 10.1146/annurev-environ-082508-094348

Moroni, S. (2020). The just city. Three background issues: institutional justice and spatial justice, social justice and distributive justice, concept of justice and conceptions of justice. Plann. Theory 19, 251-267. doi: $10.1177 / 1473095219877670$

Ohlmeyer, K., Schaefer, M., Kirstein, M., Gruehn, D., and Greiving, S. (2021). Introducing environmental-justice analysis into urban planning practices in the city of Bottrop, Germany. Town Planning Rev. 1-24.

Pearsall, H., and Anguelovski, I. (2016). Contesting and resisting environmental gentrification: responses to new paradoxes and challenges for urban environmental justice. Sociol. Res. Online 21, 121-127. doi: 10.5153/sro.3979

Pellow, D., and Brulle, R. (2005). Power, Justice, and the Environment: A Critical Appraisal of the Environmental Justice Movement. Cambridge, MA: MIT Press. Projekt Ruhr GmbH (2005). Masterplan Emscher Landschaftspark 2010. Essen

Regionalverband Ruhr/RVR (2015). Fachbeitrag Regionale Grünzüge. Essen

Regionalverband Ruhr/RVR (2016). Grüne Infrastruktur. Essen.

Regionalverband Ruhr/RVR (2019). Trägerschaft für den Emscher Landschaftspark. Evaluierungsbericht für 2019. Essen
Reimer, M., and Rusche, K. (2019). Green infrastructure under pressure. A global narrative between regional vision and local implementation. Eur. Plann. Stud. 27, 1542-1563.

Roberts, J., and Toffolon-Weiss, M. (2001). Chronide from the Environmental Justice Frontline. Cambridge, MA; New York, NY: Cambridge University Press.

Schlosberg, D. (2007). Defining Environmental Justice: Theories, Movements and Nature. Oxford: Oxford University Press.

Schlosberg, D., and Collins, L. (2014). From environmental to climate justice: climate change and the discourse of environmental justice. WIREs Clim. Change 5, 359-374. doi: 10.1002/wcc. 275

SenSW (2015). Berlin Environmental Atlas. 09.01 Environmental Justice (Edition 2015). Berlin.de. Retrieved from: https://www.stadtentwicklung.berlin.de/ umwelt/umweltatlas/ed901_03.htm

SenUVK (2017). Landschaftsprogramm. Artenschutzprogramm. Berlin: Senatsverwaltung für Umwelt, Verkehr und Klimaschutz.

Stephens, C. (2007). Environmental justice: a critical issue for all environmental scientists everywhere. Environ. Res. Lett. 2:045001. doi: 10.1088/1748-9326/2/4/045001

Stewart, I., Bacon, C., and Burke, W. (2014). The uneven distribution of environmental burdens and benefits in Silicon Valley's backyard. Appl. Geogr. 55, 266-277. doi: 10.1016/j.apgeog.2014.09.016

Travassos, L., Torres, P. H., Di Giulio, G., Jacobi, P. R., De Freitas, E., Siqueira, I. C., et al. (2021). Why do extreme events still kill in the São Paulo Macro Metropolis Region? Chronicle of a death foretold in the global south. Int. J. Urban Sustain. Dev. 13, 1-16. doi: 10.1080/19463138.2020.1762197

Zepp, H. (2018). Regional green belts in the Ruhr region. A planning concept revisited in view of ecosystem services. Erdkunde 72, 1-21. doi: 10.3112/erdkunde.2018.01.01

Zepp, H. (2020). "Das neue Emschertal. Transformation von Freiräumen und Veränderung von Ökosystemleistungen während der letzten 200 Jahre," in: Landschaft als Prozess. RaumFragen: Stadt - Region - Landschaft, eds. R. Duttmann, O. Kühne, and F. Weber (Wiesbaden: Springer VS), 327-360.

Zepp, H., Groß, L., and Inostroza, L. (2020). And the winner is? Comparing urban green space provision and accessibility in eight European metropolitan areas using a spatially explicit approach. Urban For. Urban Green. 49:126603. doi: 10.1016/j.ufug.2020.126603

Conflict of Interest: The authors declare that the research was conducted in the absence of any commercial or financial relationships that could be construed as a potential conflict of interest.

Copyright (c) 2021 Zimmermann and Lee. This is an open-access article distributed under the terms of the Creative Commons Attribution License (CC BY). The use, distribution or reproduction in other forums is permitted, provided the original author(s) and the copyright owner(s) are credited and that the original publication in this journal is cited, in accordance with accepted academic practice. No use, distribution or reproduction is permitted which does not comply with these terms. 